\title{
ДОПРИНОС КОНЦЕПТА ЉУДСКЕ БЕЗБЕДНОСТИ ПОДИЗАЊУ НИВОА СТРАТЕШКЕ КУЛТУРЕ
}

\author{
проф. др Ивица Ђорђевић ${ }^{1}$
}

\section{Апстракт}

Глобална пандемија корона вируса је показала све структурне недостатке савременог света настале као последица неолибералног уређења друштвеноекономских процеса. Сходно томе урушавање институција као ограничавајућег фактора у тежњи за максимизацијом профита довело је до немогућности система здравствене заштите да на прави начин реагују на ситуацију. Дисфункционалност здравствених система многих земаља је манифестација дубљих противуречности у актуелном капиталистичком систему. Систем који није имао адекватне корективне механизме, након пропасти СССР-а као главног идеолошког противника, дозволио је да његове полуге преузму неформалне интересне групе и да их инстурментализују за реализацију сопствених циљева. Овакво стање долази као последица губљења осећаја за стратешко промишљање и предвиђање могућих последица промена у окружењу. Стратешка култура као начин аналитичког промишљања подразумева постојање свести о свим факторима који утичу на функционисање система у садашњости, као и његову пројекцију у будућности. У датом контексту може се рећи да концепт људске безбедности због свог холистичког приступа безбедносном амбијенту представља добар аналитички оквир који путем квалитативне анализе повезује све релевантне факторе од утицаја на друштвено-економске процесе. Стабилност система зависи од економске ситуације, али и од функционалности институција. Здравље становништва зависи од економског стандарда, који директно утиче на квалитет исхране становништва, док од државног буџета зависи функционалност здравственог система. Подједнако је значајно и дијагностиковање проблема у функционисању политичког система, од кога зависи функционалност привреде, стање животног окружења, ниво криминала и безбедност заједнице. Снагом аргумената, без идеологизације анализе, концепт људске безбедности може да допринесе превенцији многих поремећаја у функционисању система, указујући на њихове узроке и могуће последице. На тај начин концепт људске безбедности повезује стратешку културу као доста апстрактан концепт са конкретним процесима и подиже свест о њеном значају.

Кључне речи: стратешка култура, концепт људске безбедности, глобализација, институције

1 Ванредни професор, Универзитет у Београду, Факултет безбедности. Е-пошта: djivica@gmail.com Ставове и закључке изнесене у тексту не треба поистовећивати са односом институције, према теми, у којој је аутор запослен. 


\section{УВОД}

Синтагма стратешка култура у литератури најчешће је повезана са расправама о рационализацији ресурса у циљу максимизације војних потенцијала. Објашњење за ову ситуацију произилази из чињенице да се стратешка култура у научним расправама и анализама појављује у време Хладног рата, када су сви ресурси западног света били усмерени ка припреми за коначни обрачун са идеолошким противником на истоку. ${ }^{2}$ У току истраживања за овај рад дошли смо до закључка да је и даље присутан тај дискурс у већини научних и стручних радова који су објављени и након пада Берлинског зида. ${ }^{3}$ Неспособност да се промени наратив у односу на тектонске промене у реалном свету генерисао је многе проблеме за које се сматрало да их неће бити када се са геополитичке сцене уклони идеолошка конкуренција.

Развојна агенција Уједињених нација (United Nations Development Programme UNDP) je 1994. године, на бази процене трендова након пет година од пада Берлинског зида, указала на чињеницу да конзерватнивни приступ безбедности није довољан за свестрано сагледавање изазова и претњи постбиполарног света. ${ }^{4}$ Развој ситуације је показао да анализа ограничена на угроженост територије и државних институција није у стању да открије главне узрочнике проблема и пружи заштиту грађанима у чијем интересу би систем требао да ради. Концепт људске безбедности је отворио нову перспективу у студијама безбедности и хуманистичким наукама уопште. Указујући на факторе који делују дестабилизујуће по систем и нудећи аналитички оквир базиран на седмодимензионалној матрици концепт људске безбедности омогућава превентивно деловање у циљу отклањања извора небезбедности. Истовремено на бази резултата истраживања базираног на концепту људске безбедности могуће је ревидирање постојећих стратегија, као и деловање у правцу промене актуелних културолошких образаца.

\section{СТРАТЕШКА КУЛТУРА}

Синтагма стратешка култура је један од назива који се могу упоредити са појавама у поп - култури. Одједном је постало популарно говорити о стратешкој култури, многи је помињу у својим радовима и свакодневном говору а да истовремено нису свесни шта се под тим подразумева. Као и већина појмова у

2 Asle Toje, „Strateška kultura kao analitički alat Istorija, mogućnosti, geopolitika i vrednosti: primer EU", Bezbednost Zapadnog Balkana, God. 4, br. 14, 2009, str. 3.

3 Такав приступ има и аутор претходно цитираног рада, као и већина домаћих аутора чији су радови базирани на, мање више, истим изворима. Милош Кнежевић је један од ретких домаћих аутора који појам стратешке културе ставља у шири социо-филозофски контекст. Видети више у: Милош Кнежевић, „Појава и појам стратешке културе - однос стратегије и културе: чему стратешка култура?", Војно дело, год. 71, бр. 8, 2019, стр. 9-31.

4 UNDP, Human Development Report, Oxford University Press, New York - Oxford, 1994. 
друштвеним наукама и стратешка култура мења своје значење у складу са променом друштвеног амбијента и оријентацијом истраживача, односно њеног корисника. У почетку резервисана искључиво за војне стратегије у односу на очекивани коначни обрачун између два супротстављена блока, односно вођење политике на нивоу држава, стратешка култура се данас помиње и у контексту доношења одлука на нивоу пословних система.

У циљу избегавања замке помодарства покушаћемо да одредимо значење на основу корена речи и понудимо оквир за анализу независан од идеолошких ограничења и догматских тумачења. Идеја је да се садржај појма одреди на основу његовог генеричког значења а у складу са промењеним друштвено-историјским околностима. У складу са полазном идејом најпре дајемо краћи осврт на појам стратегија, а затим подсећамо читаоце на значење појма култура како бисмо дошли до нашег виђења савременог значења синтагме стратешка култура.

\section{Cmpamezuja}

Стратегија је у Кембриџовом онлајн речнику одређена као: „детаљан план за остварење успеха у рату, политици, пословању или спорту, односно вештина у планирању за наведене ситуације“. 5

Вебстеров речник стратегију дефинише двојако:

- као: „Науку и уметност коришћења политичких, економских, психолошких и војних снага нације или групе нација како би се пружила максимална подршка усвојеним политикама у миру или рату“; и

- као: „науку и вештину војне команде увежбане за сусрет са непријатељима у борби како би се остварио што повољнији резултат.“

Такође, треба рећи да се у речнику наглашава разноврсност стратешких поља (области) и да успешна стратегија подразумева вештину осмишљавања плана уз адекватну методологију која је примерена жељеном циљу. ${ }^{6}$

Као и код дефинисања многих других појмова у научним анализама треба указати на античке корене појма: Реч стратегија потиче од грчке речи strategos која означава познаваоца вештине ратовања; Када погледамо и остале сродне појмове које је у контексту стратегије навео Вујаклија, онда можемо да видимо и стратегему као ратно лукавство, односно мајсторију. ${ }^{7}$

На основу изнесених дефиниција можемо да закључимо како стратегија подразумева стратешко понашање које, путем претходно испланираних активности, треба да оптимализује употреба расположивих ресурса ради

5 Cambridge Dictionary, Cambridge University Press, 2020, https://dictionary.cambridge.org/dictionary/english/strategy, Интернет: 25/08/2020.

${ }^{6}$ Merriam-Webster Dictionary, Merriam-Webster, Incorporated, 2020, https://www.merriamwebster.com/dictionary/strategy, Интернет: 25/08/2020.

7 Milan Vujaklija, Leksikon stranih reči i izraza, Beogradski izdavačko-grafički zavod, Beograd, 1980 , str. 876. 
остварења постављених циљева. У фази планирања стратегије неопходно је узети у обзир све могуће опције развоја тока догађаја, за шта нам је потребно добро познавање амбијента и свих актуелних и потенцијалних актера укључених у процес. На основу вероватноће реализације предвиђених сценарија планирају се организациони модели и предузимање акција, односно ангажовање ресурса. У савременом свету динамичних промена неопходно је дугорочно планирање како би се реализовали сопствени циљеви, задржале позиције и унапредио положај у односу на конкуренцију (супарнике, непријатеље). Зато при изради стратешких планова на значају добија примена научно заснованих система који омогућавају предвиђање будућности на основу актуелних трендова.

Међународни актери и пословни субјекти који не праве дугорочне планове стагнирају у односу на остале и осуђени су на нестанак са историјске позорнице. Стратегија се креира тако да пројектоване могуће промене у амбијенту и понашању актера мењају организациону структуру како би се максимизирали сопствени учинци и минимизирали негативни ефекти очекиваних промена.

Стратегија треба да буде резултат рационалне анализе актуелне ситуације и логичан одговор на очекиване промене. Стратешка документа треба да буду писана јасним и разумљивим стилом како би њихови корисници при операционализацији имали што мање дилема. При креирању стратегије поред узимања у обзир спољних фактора неопходно је водити рачуна и о унутрашњем амбијенту (сопственим капацитетима). Поред материјално-техничких аспеката, треба узети у обзир и људски фактор као битан елеменат, од кога зависи коначан успех пројектованих планова.

\section{Култура}

Уколико применимо исти поступак при одређењу појма култура и кренемо од Вујаклијиног лексикона, видећемо да појам потиче од латинске речи colere која значи: гајити, неговати. У датом контексту Вујаклија указује на још нека подразумевана значења појма култура:

- неговање, гајење и рационално подизање неке привредне гране;

- развијање, образовање, усавршавање, оплемењавање, богаћење духа; стручна, нарочито општа образованост; начитаност;

- етичка култура; подизање појединца и целог друштва на принципима правичности, истинитости, хуманости и узајамног поштовања;

На бази генеричког појма Вујаклија објашњава и изведени појам културан (лат. cultura), што значи однегован, усавршен, оплемењен; који има стручно и, нарочито, опште образовање. ${ }^{8}$

У Малој политичкој енциклопедији под културом се, у контексту наше теме, подразумева: „скуп свих промена и творевина које су настале у природи, друштву и људском мишљењу као последица људске делатности чији је циљ: олакшање одржања, продужења и напретка људске врсте...". По наведевном одређењу

${ }^{8}$ Milan Vujaklija, Leksikon stranih reči i izraza, оп. цит., стр. 485. 
културе њен садржај чине поред материјалних и духовни елементи попут „...обичаја, друштвених и политичких институција, религије, уметности и уметничких дела, језика, игре, наука, проналазака, открића“. 9

У Енциклопедији политичке културе пружен је детаљан приказ бројних схватања културе. Једно од занимљивих становишта односи се на схватање културолога Леслија Вајта: „Култура је једна организација појава - аката (модела понашања), предмета (оруђа, ствари направљених оруђима), идеја (веровања, сазнаја) и осећања (ставова 'вредности'), која зависи од употребе симбола. Настала је када и човек као примат који може да говори и употребљава симболе... Пошто се њени елементи лако преносе, култура постаје континуум; она вековима тече наниже, од једне генерације другој, и бочно, од једног народа другом. Културни процес је кумулативан, с времена на време елементи се уливају, и повећавају струју. Културни процес је прогресиван у том смислу што иде ка већој власти над природним силама, ка већој безбедности за човека. Култура је, према томе, симболички, континуиран, кумулативан и прогресиван процес“.10 С обзиром да о култури говоримо као нечему што представља тренутно стање које је последица дугорочних процеса у одређеном простору и времену, а за резултат има стварање индивидуалних и колективних идентитета, осећаја припадности одређеном ентитету јавља се потреба да се створене материјалне и духовне вредности сачувају од негативних утицаја. Очување сопственог културног идентитета је један од примарних циљева сваког друштва. Међутим, због емоционалног набоја који изазива традиција код људи у неким случајевима није могућ објективни однос према променама у окружењу које захтевају корекције у постојећим културолошким обрасцима. Због тога је неопходан стратешки приступ у сагледавању позиције сопственог у односу на остале ентитете и промене у окружењу. И овде долазимо до повезивања културе и стратегије, јер како каже Кнежевић: „Стратешка култура није, дакле, само стратешки обухват различитих идентитетских делова људског света у стању друштвености, него и нарочита стратегија према култури и у култури као фактору националног идентитета у условима рата и мира. Аутентична стратешка култура очитује национални и државни идентитет, па се у том погледу може означити као политика и геополитика идентитета".11

Од културолошких карактеристика умногоме зависи перцепција актуелне ситуације и спремност на промене. Успех при спровођењу планова често зависи од емоционалног односа према појави (процесу), што се односи подједнако на креаторе стратегије и на њене реализаторе. Различите биографије, припадност заједницама са одређеним друштвено-историјским детерминантама доводи до различитих реакција на исте појаве и процесе. Стратегија која је у супротности са културом ентитета коме је намењена унапред је осуђена на пропаст. Културне специфичности могу да дезавуишу и најбоље стратегије, али и да помогну у проналажењу изласка из кризе без претходних планова. У пракси можемо

\footnotetext{
${ }^{9}$ Mala politička enciklopedija, Savremena administracija, Beograd, 1966, str. 569.

${ }^{10}$ Enciklopedija političke kulture, Savremena administracija, Beograd, 1993, str. 572.

11 Милош Кнежевић, „Појава и појам стратешке културе - однос стратегије и културе: чему стратешка култура?“, Војно дело, год. 71, бр. 8, 2019, стр. 9-31.
} 
препознати и тражење алибија за неуспех у културним специфичностима оних којима је стратегија намењена (лоше предвиђање или недостатак стратегије).

Није редак случај да су стратегије наметнуте одозго, од стране тзв. елита које немају осећаја за традиционалне вредности и праксу базирану на култури ентитета којој припадају. То су ситуације када је за успех довољна само промена у приступу и аргументацији у корист пројектованих планова или избор промотера, односно реализатора стратегије.

Промена садржине појма стратегија, из данашњег угла гледано, ишла је управо са променом културолошких образаца или још боље речено са сменом цивилизација. Овом приликом не бисмо објашњавали разлику између културе и цивилизације. Читаоцима који желе да се информишу о овој теми препоручујемо литературу са списка. ${ }^{12}$ У сваком случају, стратегија у робовласничком систему античке Грчке је подразумевала војну заштиту интереса робовласника путем одбране полиса, али и офанзивне акције у циљу долажења до робова и плена. Данас се у границама савремених држава под стратегијом подразумева заштита интереса грађана који живе на њиховој територији. Међутим, данас постоје и тзв. апсолутистички диктаторски системи, у којима су циљеви стратегија очување постојећег поретка, иако на декларативном нивоу и код њих постоји позивање на заштиту интереса грађана. Са процесом глобализације долази до транснационализације многих процеса, па и повезивања реализације стратешких планова са глобалним околностима. Давно су државне стратегије престале да се баве искључиво војним аспектима заштите данас снага привреде, бројност становништва и његова припремљеност, односно мотивисаност да се бори за интересе заједнице којој припада представљају неизоставне елементе дугорочних планова.

Едвард Ерл каже да је стратегија „...у данашњем свету вештина владања и искоришћавања свих средстава којима један народ или коалиција народа располаже у датом тренутку, подразумевајући ту и оружану силу, са циљем да се његови интереси одрже и заштите од непријатеља, стварног, могућег или вероватног. Највиши тип стратегије - назван понекад високом стратегијом назива се онај тип који понекад удружује политику и оружану силу једног народа тако да прибегавање рату постаје излишна ствар или му се приступа са највећим изгледима на успех“. Ерл уочава: „...како су друштво и рат постајали сложеније појаве... то је и стратегија по сили околности захтевала обраћање све веће пажње на невојничке чињенице, економске, психолошке, моралне, политичке, војне. Према томе, стратегија није искључиво појам ратних времена, већ је саставни део државничких вештина за сва времена“. ${ }^{13}$

12 За почетак упознавања са различитим приступима у одређењу садржају појмова култура и цивилизација препоручујемо књигу: Teri Iglton, Kultura, Clio, Beograd, 2017.

13 Erl Edvard Mid, „Tvorci moderne strategije”, Vojno delo, Beograd, 1951, str. 2-3. На основу: Милош Кнежевић, „Појава и појам стратешке културе - однос стратегије и културе: чему стратешка култура?", Војно дело, год. 71, бр. 8, 2019, стр. 22. 


\section{КОНЦЕПТ ЉУДСКЕ БЕЗБЕДНОСТИ}

Пад Берлинског зида представља крај једне ере у којој је негован наратив о неизбежности коначног обрачуна између индивидуализма и колективизма (демократије и тираније). Хомогенизација западних држава је обезбеђивана перманентним подсећањем на опасност која прети са Истока. Иако није било оружаних сукоба (барем не директних) у јавном простору, однос према Источном блоку имао је сва обележја ратног стања, отуд и синтагма хладни рат. Таква друштвена клима је за резултат имала и однос према простору некадашњег Источног блока као према освојеној територији - ратном плену. Иако је постојао друштвени консензус у већини земаља некадашњег Источног блока о прихватању капитализма западног типа и интегрисању са западним земљама, гледање западних стратега према простору источних земаља је било налик односу према непријатељској територији. То је подразумевало разбијање локалних институција и пљачкашку приватизацију, која је довела до патње локалног становништва и изазвало отпор код губитника тзв. транзиционог процеса (по неким проценама преко $80 \%$ становништва). Последице транзиционог процеса на простору некадашњег Совјетског Савеза окарактерисане су као својеврсни економски геноцид. ${ }^{14}$

Последице преласка из такозваног комунизма (или социјализма) у капитализам довеле су до незадовољства код интелектуалаца и аналитичара, који су били свесни могућих последица примењеног транзиционог модела. Тај критички однос најбоље је артикулисан у оквиру Извештаја о људском развоју UNDP за 1994. годину. Аутори поменутог извештаја су на бази уочених трендова покушали да скрену пажњу креаторима светске политике на негативне појаве и њихове последице. Идеја је била да се на бази конкретних индикатора укаже на изворе проблема, као и то да се превентивно делује како би се спречило њихово испољавање у пракси. Аналитички оквир који је базиран на седам области (димензија) битних за квалитет живота и стабилност заједнице са конкретним индикаторима унутар сваке од области који се користе за квантификацију стања назван је концепт људске безбедности (КљБ). ${ }^{15}$

Суштина приступа безбедности изложеног у извештају UNDP најбоље се може схватити из следећег цитата: „Осећање несигурности већине људи потиче више од свакодневних животних брига него страха од катаклизмичних светских догађаја. Да ли ће они и њихове породице имати довољно да једу? Да ли ће изгубити посао? Да ли ће их малтретирати репресивна држава? Да ли ће постати жртве насиља због својих опредељења? Да ли ће због свог верског или етничког порекла бити мета прогањања? ... У коначној анализи, људска безбедност је дете које није преминуло, заразна болест која се није проширила, посао који није

14 Celestine Bohlen, "Yeltsin Deputy Calls Reforms Economic Genocide", The New York Times, 1992, 9. Februar, dostupno na adresi: http://www.nytimes.com/1992/02/09/world/yeltsindeputy-calls-reforms-economic-genocide.html?pagewanted=all\&src=pm (03/08/2020)

15 UNDP, Human Development Report, New York, 1994. 
одузет, етничка тензија која није експлодирала у насиље, дисидент који није ућуткан. Људска безбедност није проблем оружја - то је проблем који се тиче људског живота и достојанства“.16

Током деведесетих година прошлог и почетком овог века било је пуно расправа на тему валидности и прихватљивости концепта. Један од најзначајнијих аутора који су писали на тему КљБ је и Сабина Алкир, која је покушала да операционализује концепт, свесна чињенице да је немогуће остварити идеал апсолутне безбедности, али се зато залаже за заштиту фундаменталних људских права и могућност задовољења основних људских потреба. Алкир каже да фундаментална људска права која се тичу опстанка, средстава за живот и достојанство треба да су загарантована свим грађанима и да тај корпус права представља витално језгро људских живота. Зато је: „Циљ људске безбедности да заштити витално језгро свих људских живота од критичних и свеобухватних претњи, а да притом не доведе у питање дугорочно људско испуњење“.17

$U N D P$ је промовисао КљБ путем система ОУН уз подршку Јапана, Канаде и Норвешке као носилаца овог пројекта. Овај приступ су препознале многе мање развијене земље као начин да се коригује политика САД, тадашње једине суперсиле и њених сателита. Идеја да се безбедносна ситуација вреднује кроз призму квалитета живота грађана који живе на одређеном простору је револуционарна у односу на класични приступ државноцентричне (и/или националне безбедности), где су у први план безбедност територије и институција. Свакако да се КљБ није појавио ниоткуда, његове корене препознајемо у многим покретима борбе за равноправност људи и декларацијама о људским правима. Теоријске корене можемо да препознамо у радовима копенхашке школе и делима родоначелника студија мира Јохана Галтунга. Можемо рећи да је КљБ потекао из европског културног миљеа, у коме су још увек била свежа сећања на катастрофалне последице светских ратова. Такође, не треба занемаривати идеје на којима је успостављен систем ОУН и чињеницу да је пад Берлинског зида изазвао оптимистичка очекивања код многих интелектуалаца и прогресивно оријентисаних истраживача. Интелектуална енергија која је ослобођена са отклањањем опасности од нуклеарног холокауста бива преусмерена ка пројектовању и изградњи једног праведнијег и хуманијег света глобалних грађана. Стиче се утисак да је култура мира која је, барем званично, изграђивана након Другог светског рата далеко превазишла капацитете стратега који су креирали глобални амбијент током 90-их година XX века.

Поред претходног кратког приказа КљБ треба рећи још пар напомена битних за разумевање суштине идеје. Оригинални концепт није у сукобу са државом и постојећим институцијама, напротив, КљБ се залаже да постојећи институционални механизми штите права грађана, што је и њихова основна

16 Ibid., p. 22.

17 Sabina Elkir: „Konceptualni okvir za ljudsku bezbednost” u: Dulić Dragana ured., Ljudska bezbednost 1, Zbornik tekstova, Fond za otvoreno društvo, Beograd, 2006. str.91. 
функција. Такође, КљБ треба посматрати и у контексту захуктале економске глобализације, коју није пратила одговарајућа глобална институционална инфраструктура. Инсистирање на поштовању фундаменталних људских права подразумева да се једнако третирају сви људи на планети земљи независно од тога да ли су грађани развијених или неразвијених земаља. Управо на бази идеје о универзализацији приступа дат је аналитички оквир који вреднује ниво безбедности на бази седам области битних за квалитет живота људи независно од њихове верске, расне или неке друге припадности.
1. Економска безбедност,
5. Лична безбедност,
2. Безбедност исхране,
6. Безбедност заједнице и
3. Безбедност здравља,
7. Политичка безбедност. 18
4. Еколошка безбедност,

У оквиру сваке од димензија могућ је избор низа индикатора који служе за квантификацију стања. С тим што није увек обавезан избор истог сета индикатора, јер специфичност ситуације на терену захтева диференцијацију приступа. На пример, нећемо изабрати исте приоритете при анализи сиромашних, неразвијених земаља и развијених земаља. Ова сензитивност се често користи као аргумент у прилог томе да КљБ није методолошки конзистентан, те као такав није прихватљив за академску заједницу. По нашем мишљењу то је квалитет више, јер за сиромашне, неразвијене земље, врло често, приоритет представља обезбеђивање средстава за неопходан минимум хране и исправне воде за пиће, док је за неке од развијених земаља највећи проблем кршење демократских процедура. Званични статистички подаци публиковани од стране националних и међународних организација су базични материјал за анализу стања безбедности људи, али поред тога врло битан моменат представља и захтев за истраживањем субјективног доживљаја ситуације од стране људи који живе на простору који је у фокусу истраживања. Није ретка ситуација да званичне статистике нису сензитивне за проблеме одређених друштвених група (становника одређеног региона, припадника мањинске заједнице или сиромашнијег дела популације). Зато је истраживање на терену један од захтева који се поставља пред истраживаче који КљБ користе као аналитички оквир. Зависно од услова истраживања примениће се неки од инструмената попут анкете или интервјуа како би се дошло до информација које нису доступне из постојећих статистичких извора.

18 UNDP, Human Development Report. New York - Oxford, Oxford University Press, 1994, p. 2425. 


\section{УТИЦАЈ КОНЦЕПТА ЉУДСКЕ БЕЗБЕДНОСТИ НА НИВО СТРАТЕШКЕ КУЛТУРЕ}

Коришћење Концепта људске безбедности као аналитичког оквира који омогућава квантификацију стања безбедности на неком простору путем мерљивих индикатора омогућава да се постојећа ситуација критички анализира. На бази праћених података могуће је благовремено реаговати у циљу промене негативних трендова, као и утицаја на промену праксе која доводи до негативних појава. Егзактни показатељи могу да се искористе за разбијање предрасуда које су прихваћене на нивоу догматских уверења. На пример, једна од највећих заблуда која је унесрећила милионе људи на планети и довела до питања одрживости и опстанка читаве савремене цивилизације је уверење да тржишни закони могу да регулишу све процесе и односе међу људима.

КљБ може да објективизује многе критике на рачун функционисања савремене цивилизације. На бази доступних економских индикатора може да се види које су државе успешније у обезбеђивању услова за реализацију потенцијала њихових грађана, њихове безбедности и стабилности система. Доступни подаци говоре да је најквалитетнији живот оних људи који су на територијама где постоје корективни механизми у односу на функционисање тржишних закона. На листама које рангирају задовољство грађана условима живота нису прворангиране државе које фаворизују тржишни фундаментализам ни оне које су се определиле за доминантну улогу у планирању привредних активности. Напротив, међу првих 10 рангираних су земље које су препознатљиве по значајним социјалним програмима намењених угроженим деловима популације. ${ }^{19}$ У односу на актуелну ситуацију са пандемијом изазваном вирусом COVID-19 испоставило се да земље које су безрезервно прихватиле смернице из вашингтонског консензуса ${ }^{20}$ и прешле на приватизацију државног здравственог система имају најтеже последице исказане кроз број умрлих и оболелих. Иако су постојала упозорења да нови модел носи велике ризике због уштеде буџетских средстава, земље попут САД и Велике Британије су се определиле за рестриктивну политику у финансирању здравствених система. ${ }^{21}$

Једна од најконтроверзнијих тема савременог света је примена генетски модификованих организама (ГМО) у људској исхрани, која се форсира од стране носилаца патената за одређене биљне и животињске врсте. На основу резултата истраживања објективних независних истраживача може да се види како

19 John F. Helliwell et al., eds. “World Happiness Report 2020”, Sustainable Development Solutions Network, New York, 2020. pp. 19-21.

${ }^{20}$ Hannah Ritchie at all, "Coronavirus Pandemic (COVID-19) - Research and data", Our World in Data, Oxford Martin School - University of Oxford, https://ourworldindata.org/coronavirus (25/08/2020).

21 Ivica Đorđević, Bezbednosna arhitektura u uslovima globalizacije, Fakultet bezbednosti Službeni glasnik, Beograd, 2007. str. 26. 
проблем са количинским дефицитом и квалитетом хране није решен захваљујући ГМО. Напротив, постоје озбиљне сумње да непоштовање процедура при истраживању утицаја ГМО на здравље људи и еколошке системе, доноси више штете него користи човечанству. ${ }^{22}$

Због третирања природе као неекономског добра дошло је до драстичног нарушавања природне равнотеже и нестанка многих врста биљног и животињског света. Штете су неповратне, а заступници интереса ТНК и даље врше опструкцију усвајања и примене мера за заустављање девастације планете и њених ресурса. ${ }^{23}$

Учешће и заинтересованост грађана за политичке процесе се све више смањује. Смањена излазност на изборе указује на чињеницу да су људи изгубили веру у систем. Посебан апсурд у савременом свету представља чињеница да најобразованији део популације не учествује у политичким процесима. Због природе после и велике флуктуације, честе промене места боравка, истраживачи и научници, односно припадници управљачке елите ТНК нису заинтересовани за локалне политичке процесе и не учествују у изборним активностима. Трендови показују да долази до општег пада излазности гласача на изборе. Тај пад је сразмеран у демократским и недемокртским системима, једина је разлика између стартних позиција. Постоји једна занимљива појава која је регистрована између демократских и недемократских система, где је излазност скоро изједначена, док је у полудемократским системима најмања излазност. Та појава се може објаснити страхом гласача од апсолутистичке структуре на власти, да ће трпети последице уколико не изађу на изборе. ${ }^{24}$

Лична и социјална безбедност представљају све више изазов због нараслих социјалних разлика, које за резултат имају пораст криминала, како на локалном, тако и на глобалном нивоу. Безбедност заједнице и друштвених група је додатно проблематизована због великих миграторних таласа и културолошких разлика између имиграната и домаћег становништва. 25

Институционални систем није увек у служби интереса грађана који живе на његовој територији. Чести су примери да војно-полицијске структуре

22 Jeremy Rifkin, Biotehnološko stoljeće - Trgovina genima u osvit vrlog novog sveta, Naklada Jesenski i Turk, Hrvatsko sociološko društvo, Zagreb, 1999.

23 Јасмина Гачић, “Одрживи развој” у: Ивица Љ. Ђорђевић, Марко Филијовић и Јасмина Гачић, Безбедност економија и одрживи развој, Факултет безбедности, Београд, 2017. стр. 302-308.

${ }^{24}$ Abdurashid Solijonov, Voter Turnout Trends around the World, International Institute for Democracy and Electoral Assistance, Stockholm, 2016, p.29.

25 Сажети приказ проблема са великим приливом имиграната у Европу може да се прочита у чланку објављеном у Београдском дневном листу Политика поводом изјаве немачке канцеларке Ангеле Меркел да је „Покушај стварања мултикултуралног друштва пропао, апсолутно пропао”. Видети више у: Милош Казимировић, „Меркелова и смрт мултикултурализма", Политика, 12.jануар 2015, онлајн издање: http://www.politika.rs/scc/clanak/315768/Tema-nedelje/Veliki-nesporazumcivilizacija/Merkelova-i-smrt-multikulturalizma (25/08/2020.) 
представљају отуђене центре моћи и бивају инструментализовани за реализацију интереса неформалних група (најчешће олигархије). Цивилна контрола министарстава силе је једини гарант да овај сегмент институционалног система неће бити злоупотребљен. Међутим, имајући у виду претходне напомене, тешко је обезбедити функционисање демократских механизама контроле када и само бављење политиком постаје привилегија богатих.

Неоконзервативни приступ уређењу друштвено-економских токова, који је наметнут као идеолошки пројекат власника (контролора) крупног капитала у савременим околностима показује катастрофалне резултате. Ефекти неоконзервативног модела наметнутог путем вашингтонских консензуса као образац за транзиционе промене у пракси је дао толико лоше резултате да је довео у питање и догматску матрицу о супериорности капитализма над свим осталим облицима уређења. То се најбоље показало у истраживању Европске банке за обнову и развој које показује да у транзиционим земљама људи више не верују у демократске форме организације друштвених система и више су окренути ка апсолутистичким системима. ${ }^{26}$

\section{ЗАКЉУЧАК}

Неконтролисана глобализација привредних активности и финансијских токова омогућила је доминантни положај и стварање олигопола на глобалном нивоу, у неким областима постоји тенденција ка монополизацији глобалног тржишта од стране највећих транснационалних компанија. Огромни фондови којима располажу управни одбори ТНК омогућавају да се успоставља светска структура по мери интереса ових профитно оријентисаних ентитета. Користећи непостојање глобалних система контроле пословања и правила која би их спутавала ТНК креирају глобални амбијент у коме максимизирају своје приходе на рачун експлоатације радне снаге, уништавања природних ресурса и осиромашења националних држава.

На основу изречених ставова неко би покушао да дисквалификује критику система, етикетирајући је као комунистичку, односно идеолошки неприхватљиву. Међутим, уколико иза изнесених оштрих осуда актуелне праксе у пословању ТНК стоје конкретни статистички подаци који се могу добити на бази истраживања националних статистичких завода, међународних институција (попут светске банке и $U N D P$ ), онда упозорења која долазе од истраживача имају далеко већу снагу. Овде је потребно посебно нагласити да КљБ није револуционарна идеологија која треба да силом мења постојећи поредак. Напротив, идеја је да се изврши еволутивна трансформација система и да постојеће институције раде свој

26 EBRD, Life in Transition, After the Crisis, European Bank for Reconstruction and Development, London, 2011, p. 22. 
посао због чега су и успостављене. У супротном прети опасност да систем институција буде инструментализован од стране крупног капитала и да ради против интереса грађана.

Основни проблем који постоји у центру капиталистичког система је тај што се није трансформисао у складу са променама које су наступиле након пада Берлинског зида. Доминантна секјуритизација кључних научних института за време Хладног рата, посебно друштвених наука, била је у функцији доказивања супериорности западног поретка у односу на идеолошког противника са истока. Уместо преоријентације на критичко изучавање сопственог система и пројектовање нових модела у складу са доминантним глобалним процесима западна мејнстрим наука тежи наметању превазиђених концепата остатку света. Десио се један парадоксалан процес, идеологија која је омогућила победу у Хладном рату бацила је на колена победника. У прилог изнесене тезе користимо податке о скраћивању времена између цикличних криза капиталистичког система. Неки економисти тврде како је капитализам у епизоди пролонгираног успореног раста (што би лаичким речником могли рећи да се капитализам налази у перманентној кризи) од 2008. године. ${ }^{27}$

У време Хладног рата атрактивност друштвених теорија са запада долази као последица, између осталог, и веће слободе научника у односу на критички однос према истраживаним феноменима. Из ове перспективе можемо сада да кажемо како је та слобода била привид како би се свет убедио да је систем бољи и хуманији у односу на идеолошког противника. Посебан квалитет том систему давао је велики број дисидената који су долазили иза гвоздене завесе, али и велики број лево оријентисаних теоретичара који су представљали својеврсни коректив систему. Са падом Берлинског зида долази до наметања конзервативних аутора попут Фукујаме 28 (који глорификује постојећи капиталистички систем) и Бжежинског ${ }^{29}$ (који се понашао као да рат између истока и запада још увек постоји). Стиче се утисак како се није размишљало о прилици која постоји за успостављање новог светског поретка заснованог на

27 Aleksandra Praščević, „Od globalne ekonomske krize do krize globalnog kapitalizama”, Ekonomske ideje i praksa, br. 24. 2017, str. 7-21.

28 Аутор једне од најконтроверзнијих књига, коју многи поистовећују са политичким памфлетом: Frensis Fukujama, Kraj istorije i poslednji čovek, CID, Podgorica, 2002.

29 Особа која је значајно утицала на спољну политику САД на крају XX века. Острашћени противник сваке идеје о компромису између два идеолошка система. Одредио је правац САД политике након пада Берлинског зида и најавио неке процесе чији смо ми данас савременици. Видети више у: Zbignjev Bžežinski, Velika šahovska tabla, Романов, Бања Лука, 2001. 
принципима које је победник у току Хладног рата глорификовао већ о капитализацији победе у смислу глобалне контроле.

Једно од решења за кризу система је да се на основу уочених проблема предузму кораци како би се исти уклонили. Уочени демократски дефицит се може решити путем враћања полуга власти на управу представницима грађана који се бирају на непосредним изборима на локалном нивоу. Изабрани представници би за свој изборни програм одговарали пред својим бирачима. Тиме би се обезбедила већа заинтересованост грађана за изборни процес и натерали политичари да воде рачуна о резултатима својих активности у периодима између изборних циклуса. Непосредна демократија би допринела оптимизацији трошења буџетских средстава на задовољење потреба грађана и смањила би простор за коруптивну праксу. Политичари који су свесни своје одговорности у односу на бирачко тело водили би рачуна о интересу грађана при доношењу закона и њиховом спровођењу.

Један од највећих проблема са којима се суочавају савремене државе је хронични дефицит у приходима који се, како сада ствари стоје, надокнађује повећањем пореског оптерећења грађана. Враћање на принцип прогресивног опорезивања би успоставио праведнији однос при финансирању заједничких потреба у односу на финансијску моћ пореских обвезника. Праведнија расподела друштвеног богатства са повећањем дела од прихода који иде непосредним учесницима у производњи и пружању услуга утицала би на подизање нивоа квалитета живота грађана. Синергија ова два процеса - више средстава у буџету и већи приходи грађана - омогућила би квалитетније образовање које смањује простор за манипулацију бирачким телом и правима грађана, подиже ниво квалитета здравственог система, мења однос према животном окружењу и онемогућава прекарни однос према радној снази.

Реализацијом потенцијала који у себи носи КљБ, у датом контексту, представља прилику за еволутивни прелазак капиталистичког система на виши ниво организације и функционисања. Подизање свести о узроцима кризе и последицама евентуалних револуционарних промена требало би да утиче на актуелне политичке чиниоце да се што пре врате на поставке капитализма промовисане након Другог светског рата ${ }^{30}$ и поново актуелизовање идеала државе благостања. ${ }^{31}$ у супротном, даља комерцијализација свих сегмената људских активности (па и самих људи) довешће до наставка ретроградних

\footnotetext{
30 Ayn Rand, Kapitalizam nepoznati ideal, Global book, Novi Sad, 1994.

31 Slobodanka Nedović, Država blagostanja, Centar za unapređenje pravnih studija, Beograd, 2005.
} 
тенденција у систему и даљих заоштравања противуречности унутар система. Имајући у виду манипулативни потенцијал нових технологија (пре свега информационо-комуникационих), чија је употреба потпуно ван институционалне контроле, опасност постаје све већа. Враћање полуга институционалне контроле под управу демократски изабраних представника народа представља предуслов преокретању негативних трендова. Тај процес подразумева подизање нивоа безбедносне културе на глобалном нивоу, чему значајан допринос може да пружи опште прихватање принципа на којима се базира КљБ. Подизање нивоа свести о значају демократски контролисаних институција и њиховој трансформацији у односу на глобалне трендове представља једини начин за превазилажење актуелне кризе изазване корона вирусом, али и свих осталих проблема са којима се савремена цивилизација суочава.

\section{БИБЛИОГРАФИЈА}

1. Bohlen Celestine, "Yeltsin Deputy Calls Reforms Economic Genocide", The New York Times, 1992, 9. februar, Internet: http://www.nytimes.com/1992/02/09/world/yeltsin-deputy-calls-reformseconomic-genocide.html?pagewanted=all\&src=pm 03/08/ 2020.

2. Bžežinski Zbignjev, Velika šahovska tabla, Романов, Бања Лука, 2001.

3. Đorđević Ivica, Bezbednosna arhitektura u uslovima globalizacije, Fakultet bezbednosti - Službeni glasnik, Beograd, 2007.

4. Ђорђевић Љ. Ивица, Филијовић Марко и Гачић Јасмина, Безбедност економија и одрживи развој, Факултет безбедности, Београд, 2017.

5. Vujaklija Milan, Leksikon stranih reči i izraza, Beogradski izdavačko-grafički zavod, Beograd, 1980.

6. EBRD, Life in Transition, After the Crisis. European Bank for Reconstruction and Development, London, 2011.

7. Elkir Sabina: „Konceptualni okvir za ljudsku bezbednost” u: Dulić Dragana ured., Ljudska bezbednost 1, zbornik tekstova, Fond za otvoreno društvo, Beograd, 2006.

8. Iglton Teri, Kultura, Clio, Beograd, 2017.

9. Казимировић Милош, „Меркелова и смрт мултикултурализма“, Политика, 12. јануар 2015, онлајн издање: http://www.politika.rs/scc/clanak/315768/Temanedelje/Veliki-nesporazum-civilizacija/Merkelova-i-smrt-multikulturalizma 25/08/2020

10. Кнежевић Милош, „Појава и појам стратешке културе - однос стратегије и културе: чему стратешка култура?“, Војно дело, 71(8), 2019.

11. Mala politička enciklopedija, Savremena administracija, Beograd, 1966. 
12. Merriam-Webster Dictionary, Merriam-Webster, Incorporated, 2020, https://www.merriam-webster.com/dictionary/strategy, 25/08/2020.

13. Mid Erl Edvard, „Tvorci moderne strategije“, Vojno delo, Beograd, 1951.

14. Nedović Slobodanka, Država blagostanja, Centar za unapređenje pravnih studija, Beograd, 2005.

15. Praščević Aleksandra, „Od globalne ekonomske krize do krize globalnog kapitalizama“, Ekonomske ideje i praksa, br. 24.

16. Rand Ayn, Kapitalizam nepoznati ideal, Global book, Novi Sad, 1994.

17. Rifkin Jeremy, Biotehnološko stoljeće - Trgovina genima u osvit vrlog novog sveta, Naklada Jesenski i Turk, Hrvatsko sociološko društvo, Zagreb, 1999.

18. Ritchie Hannah at all, "Coronavirus Pandemic (COVID-19) - Research and data”, Our World in Data, Oxford Martin School - University of Oxford, https://ourworldindata.org/coronavirus, 25/08/2020.

19. Solijonov Abdurashid, Voter Turnout Trends around the World, International Institute for Democracy and Electoral Assistance, Stockholm, 2016.

20. Toje Asle, „Strateška kultura kao analitički alat Istorija, mogućnosti, geopolitika i vrednosti: primer EU”, Bezbednost Zapadnog Balkana, Godina 4, br. 14, 2009, Str.3. (3-23).

21. UNDP, Human Development Report, Oxford University Press, New York - Oxford, 1994.

22. Fukujama Frensis, Kraj istorije i poslednji čovek, Podgorica, 2002.

23. Helliwell F. John, Layard Richard, Sachs D. Jeffrey, and De Neve Jan-Emmanuel, eds. (2020). World Happiness Report 2020, Sustainable Development Solutions Network, New York, 2020.

24. Cambridge Dictionary, Cambridge University Press, 2020, https://dictionary.cambridge.org/dictionary/english/strategy, 25/08/2020.

\section{CONTRIBUTION OF THE HUMAN SECURITY CONCEPT TO RAISING THE LEVEL OF STRATEGIC CULTURE}

The global corona virus pandemic has shown all the structural shortcomings of the world resulting from the neoliberal regulation of socio-economic processes. The process of institutions collapsing as a limiting factor in the process of profit maximization has led to the fact that health care systems are not able to react in the right way in relation to the situation. The dysfunctionality of the health systems of many countries is a manifestation of deeper contradictions in the current capitalist system. The system that did not have adequate corrective mechanisms allowed its levers to be taken over by informal interest groups and instrumentalized for the realization of their own goals after the collapse of the USSR as the main ideological opponent. This situation 
comes as a consequence of losing the sense of strategic thinking and anticipating the possible consequences of change of the environment. Strategic culture as a way of analytical thinking implies the existence of awareness of all factors that affect the functioning of the system in the present, as well as its projection in the future. In the given context, it can be said that the concept of human security is a good analytical framework that, through qualitative analysis, connects all relevant factors influencing socio-economic processes due to its holistic approach to the security environment. The stability of a system depends on the economic situation, but also on the functionality of the institutions. The health of the population depends on the economic standard that directly affects the quality of nutrition of the population, while the functionality of the health system depends on the state budget. Diagnosing problems in the functioning of the political system, on which the functionality of the economy, the state of the environment, the level of crime and the security of the community depend is no less important. By the power of arguments, without ideologizing the analysis, the concept of human security can contribute to the prevention of many disturbances in the system functioning by pointing out their causes and possible consequences. In this way, the concept of human security connects strategic culture as a rather abstract concept with concrete processes and raises awareness of its importance.

Keywords: strategic culture, human security concept, globalization, institutions 